\title{
Effects of storage temperature and time on false setting behavior of CPI-S Portland cement
}

\section{(Efeitos da temperatura e do tempo de armazenamento no comportamento de falsa pega do cimento Portland CPI-S)}

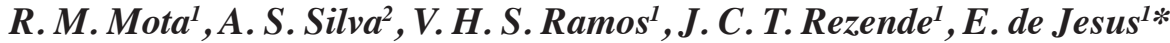 \\ ${ }^{I}$ Federal University of Sergipe, Department of Chemical Engineering, Av. Marechal Rondon, $s / n$, \\ São Cristóvão, SE, Brazil \\ ${ }^{2}$ Federal University of Sergipe, Department of Mathematics, São Cristóvão, SE, Brazil
}

\begin{abstract}
The false setting is when cement stiffens prematurely in a few minutes after adding water. Some variables could cause false setting in CPI-S-32 Portland cement, for example, alkali concentration in the cement, the formation of alite $\left(\mathrm{C}_{3} \mathrm{~S}\right)$ with low reactivity, and cement storage temperature and time in silos. Temperature increases cause calcium sulfate dihydrate to dehydrate, forming hemihydrate $\left(\mathrm{CaSO}_{4} \cdot 0.5 \mathrm{H}_{2} \mathrm{O}\right)$ or anhydrite $\left(\mathrm{CaSO}_{4}\right)$, which causes the false setting. In this study, the influence of cement storage temperature $\left(100,105,110,120\right.$, and $\left.130^{\circ} \mathrm{C}\right)$ combined with the cement storage time $(30,60$, and 120 min) in a silo was studied regarding the CPI-S-32 false setting behavior. It was verified that temperatures above $110{ }^{\circ} \mathrm{C}$ and storage time above 60 min are conditions that favor the false setting of CPI-S-32 cement. Physicochemical analysis, TG/DTG, XRF, and XRD were applied as complementary analyzes for the false setting assays of CPI-S-32.
\end{abstract}

Keywords: false setting, CPI-S-32 Portland cement, cement storage temperature, cement storage time.

Resumo

Falsa pega é a denominação dada ao enrijecimento prematuro anormal do cimento em poucos minutos após a adição de água. Alguns fatores podem ocasionar falsa pega no cimento Portland CPI-S-32, por exemplo, concentração de álcalis no cimento, formação de alita $\left(C_{3} S\right)$ com baixa reatividade e temperatura e tempo de armazenamento do cimento nos silos. $O$ aumento da temperatura causa a desidratação do sulfato de cálcio di-hidratado formando o hemi-hidrato $\left(\mathrm{CaSO}_{4} .0,5 \mathrm{H}_{2} \mathrm{O}\right)$ ou anidrita $\left(\mathrm{CaSO}_{4}\right)$, que causa a falsa pega. Assim, neste trabalho foi avaliada a influência da temperatura de armazenamento do clínquer (100, 105, 110,120 e $130{ }^{\circ} \mathrm{C}$ ) combinada com o tempo de armazenamento do cimento (30, 60 e 120 min) no comportamento de falsa pega do CPI-S-32. Foi verificado que temperatura de armazenamento acima de $110{ }^{\circ} \mathrm{C}$ e tempo de armazenamento acima de 60 min são condições que favorecem a falsa pega do cimento CPI-S-32. Análises físico-químicas, TG/DTG, FRX e DRX foram utilizadas como análises complementares aos ensaios de falsa pega do CPI-S-32.

Palavras-chave: falsa pega, cimento Portland CPI-S-32, temperatura de armazenamento, tempo de armazenamento.

\section{INTRODUCTION}

The population growth, as a rule, causes an increase in materials used for housing construction [1], and cement can be highlighted among these materials. Cement can be defined as a material with adhesive and cohesive properties, which make it able to join mineral fragments in the form of a compact unit [2]. Portland cement is a hydraulic binder obtained by grinding a Portland clinker with the addition of one or two forms of calcium sulfate during the production process. Portland cement CPI-S-32 is composed of $6 \%$ to

*edilsonjs@ufs.br

Dhttps://orcid.org/0000-0003-4239-6050
$10 \%(\mathrm{~m} / \mathrm{m})$ of carbonate material containing at least $75 \%$ $\mathrm{CaCO}_{3}$ [3] processed by milling [4-6]; during the cement milling and storage stages, operational parameters must be controlled according to NBR 16697 standard. Among these parameters, the cement storage temperature may cause an alteration in the physical-chemical behavior of cement, such as the anomalous behavior of a false setting. Gypsum is added to the clinker in this stage to delay the hydration reaction of tricalcium aluminate $\left(\mathrm{C}_{3} \mathrm{~A}\right)$, which is the clinker constituent that features the biggest reactivity with water.

The reactions in which the CPI-S becomes a binder material occur in the paste, constituted by the direct addition of some water molecules and cement. In other words, the presence of water and the silicates and aluminates of cement create hydrated products, which result in a resistant 
and steady mass over time. Among the several hydration products of CPI-S, the hydration reaction of silicates, calcium hydroxide, and aluminates can be highlighted. Both calcium silicates, named as tricalcium silicate or alite $\left(\mathrm{C}_{3} \mathrm{~S}\right)$ and dicalcium silicate or belite $\left(\mathrm{C}_{2} \mathrm{~S}\right)$, are the main components of cement, with the first experiencing hydration faster than the second [7] due to higher reaction speed compared to the $\mathrm{C}_{2} \mathrm{~S}$, considering that $\mathrm{C}-\mathrm{S}-\mathrm{H}$ gel is the final complete hydration product of both $\mathrm{C}_{3} \mathrm{~S}$ and $\mathrm{C}_{2} \mathrm{~S}[7,8]$. Furthermore, both calcium silicates during their hydration form the hydrated calcium silicate (C-S-H), which performs a dominant role in determining the mechanical and physicalchemical properties of the concrete [9]. The C-S-H normally consists of $50 \%$ to $60 \%$ of the solid volume in a fully hydrated cement paste, therefore being the most important phase in determining the properties of the paste. Unlike $\mathrm{C}-\mathrm{S}-\mathrm{H}$, calcium hydroxide has its stoichiometry defined as $\mathrm{Ca}(\mathrm{OH})_{2}$ and constitutes $20 \%$ to $25 \%$ of the solid volume in the hydrated cement paste. However, the $\mathrm{C}_{3} \mathrm{~A}$ reaction with water is immediate and creates crystalline hydrates of $\mathrm{C}_{3} \mathrm{AH}_{6}$ (tricalcium aluminate hydrate), $\mathrm{C}_{4} \mathrm{AH}_{19}$ (hexagonal calcium aluminate hydrate), and $\mathrm{C}_{2} \mathrm{AH}_{8}$ (dicalcium aluminate hydrate) with heat release, and occupy around $15 \%$ to $20 \%$ of the solid volume in a hydrated cement paste [10]. In the hydration process of CPI-S, both the hydration of $\mathrm{C}_{3} \mathrm{~A}$ and its hydration in the presence of gypsum are important, being responsible for slowing down the hydration reaction and the immediate setting of the cement. This effect can be explained by the fact that when gypsum and alkalis go into solution quickly, the $\mathrm{C}_{3} \mathrm{~A}$ solubility is reduced in the presence of hydroxyl, sulfate, and alkalis [8].

The setting refers to the cement paste going from a fluid state to a rigid state where the paste acquires a certain consistency which makes it improper for work, and in which the physicochemical process occurs by means of exothermal reactions. The initial setting is the start of plasticity loss in the water and cement mixture, followed by the paste temperature rising. The final setting is when the paste ceases to be deformed by a small load and starts to form a rigid block. In addition to the setting, another behavior that is highlighted in CPI-S cement is the false setting, which is when abnormal premature stiffening of the cement occurs a few minutes after adding water. False setting differs from the instantaneous setting since there is no important heat release [10]. When the cement $\mathrm{C}_{3} \mathrm{~A}$ has low reactivity, as is the case of partially hydrated cement or carbonated cement that may have been stored in inappropriate form, and a large amount of gypsum is present in the cement at the same time, the solution will contain a low concentration of aluminate ions, making it rapidly supersaturated with calcium and sulfate ions, leading to the rapid formation of large gypsum crystal with a corresponding loss in the consistency, which therefore causes the false setting of the cement [8].

Some factors influence the false setting in CPI-S such as cement alkalis, the activation of $\mathrm{C}_{3} \mathrm{~S}$ due to high moisture, the clinker milling temperature, and storage temperature and time of cement in silos. Partially calcined gypsum
$\left(\mathrm{CaSO}_{4} \cdot 2 \mathrm{H}_{2} \mathrm{O}\right)$ loses $75 \%$ of its crystallization water, forming a hemihydrate or basanite $\left(\mathrm{CaSO}_{4} \cdot 0.5 \mathrm{H}_{2} \mathrm{O}\right)$ or anhydrite $\left(\mathrm{CaSO}_{4}\right)$ which possesses five times more solubility than gypsum, and then forms a supersaturated solution when mixed with water which tends to deposit dihydrate crystals. Moreover, the cement hydrates in needle calcium sulfate form when mixed with water. Thus, a false setting can be named 'calcium sulfate setting', resulting in the paste stiffening $[7,8,10,11]$. In a previous study [12], calcium sulfate hemihydrate was the first chemical species of gypsum dehydration, in which the reaction process began at $106{ }^{\circ} \mathrm{C}$. In another study [13], the occurrence of gypsum dehydration was maximized at temperatures above $125^{\circ} \mathrm{C}$, which led to the cement presenting false setting behavior. An additional factor that must be studied is the storage time of cement in silos. This can cause a false setting as a result of the cement compacting inside the silo, causing a rise in the temperature of the stored cement and, consequently, dehydration reactions in the CPI-S. There are generally aeration systems in the silos which cause the cement to be in constant movement, preventing the increase in cement temperature. This storage period must be sufficient for the cement to lose the necessary heat in the interior of silos before shipping, as this factor can be crucial to the occurrence of problems in the concrete. Thus, the objective of the present study is to evaluate the influences of the storage temperature and time of cement on the false setting behavior of CPI-S-32, which is the Portland cement with the highest production volume in the Brazilian market, used in general construction services with no special properties required.

\section{MATERIALS AND METHODS}

Preparation of raw materials: the clinker used in this study came from the clinkerization process of a cement company located in Capanema-PA (Brazil). First, $55 \mathrm{~kg}$ of clinker was processed in a jaw crusher (Pragotec, 3020) for the granulometric reduction of the material. After crushing, clinker grinding was performed using a disc mill (Renard, MSA 200-4472) until all the material reached a particle size that was able to pass through a 170-mesh sieve (NBR 14656). The homogenization was performed in a mechanical mixer (Pragotec, Type V) with three volumetric chambers. This stage was necessary to ensure the clinker samples had uniformity. The gypsum was supplied by a cement company located in Capanema-PA (Brazil). The raw material was initially placed in an oven (Fanem, $313 / \mathrm{SE}$ ) at $55 \pm 5^{\circ} \mathrm{C}$ for $10 \mathrm{~h}$. After this treatment, $8.0 \mathrm{~kg}$ of gypsum was milled in the disc mill until all the material reached between $1.0 \%$ and $3.5 \%$ of material retained in a 325 -mesh sieve. Next, homogenization was performed in a plastic bag and stored in the plastic bag itself. The limestone was provided by a cement company located in Capanema-PA (Brazil). The material was initially dried in the oven at $110 \pm 10^{\circ} \mathrm{C}$ for $2 \mathrm{~h}$. Next, $8.0 \mathrm{~kg}$ of this material was ground in the disc mill until all the material presented a particle size passing through a 170-mesh sieve. Next, the homogenization was performed 
in a plastic bag and then stored.

Preparation of CPI-S-32 cement: CPI-S-32 was prepared by mixing $88.5 \%$ clinker, $5.5 \%$ gypsum, and $6.0 \%$ limestone (mass percent) using a ball mill (Pragotec, 1A). The milling operation produced a material with $4.0 \%$ to $6.5 \%$ of granulometry retained in a 325-mesh sieve. Lastly, homogenization was performed in a plastic bag. Influence of storage temperature and time: samples containing $3.0 \mathrm{~kg}$ of CPI-S-32 were stored in the oven at different temperatures $\left(100,105,110,120\right.$ and $\left.130{ }^{\circ} \mathrm{C}\right)$ and different times $(30,60$ and $120 \mathrm{~min}$ ) inside metal containers with a height of $52 \mathrm{~mm}$ and diameter of $304 \mathrm{~mm}$ (simulating the storage in a silo), according to Table I. The samples were stored at atmospheric pressure (1 atm).

Table I - Experimental conditions of the CPI-S-32 sample production.

[Tabela I - Condições experimentais de produção das amostras de CPI-S-32.]

\begin{tabular}{ccc}
\hline CPI-S-32 sample & Temperature $\left({ }^{\circ} \mathrm{C}\right)$ & Time $(\mathrm{min})$ \\
\hline CPI-S 100.30 & 100 & 30 \\
CPI-S 100.60 & 100 & 60 \\
CPI-S 100.120 & 100 & 120 \\
CPI-S 105.30 & 105 & 30 \\
CPI-S 105.60 & 105 & 60 \\
CPI-S 105.120 & 105 & 120 \\
CPI-S 110.30 & 110 & 30 \\
CPI-S 110.60 & 110 & 60 \\
CPI-S 110.120 & 110 & 120 \\
CPI-S 120.30 & 120 & 30 \\
CPI-S 120.60 & 120 & 60 \\
CPI-S 120.120 & 120 & 120 \\
CPI-S 130.30 & 130 & 30 \\
CPI-S 130.60 & 130 & 60 \\
CPI-S 130.120 & 130 & 120 \\
\hline
\end{tabular}

For all conditions: the mass composition was $88.5 \%$ clinker, $5.5 \%$ gypsum, and $6.0 \%$ limestone; the response variable was false setting.

Determination of the CPI-S-32 false setting: determination of false setting was performed in accordance with the ASTM C451-13 standard [14]. The CPI-S-32 paste preparation was performed in a room at $23 \pm 2{ }^{\circ} \mathrm{C}$ and relative humidity higher than $50 \%$, with $350.0 \pm 0.1 \mathrm{~g}$ of CPI-S-32 cement and $122.5 \pm 0.1 \mathrm{~g}$ of distilled water. The water-cement CPI-S-32 paste was prepared in a stainless vat, and the mixing was performed with the aid of a spreader for $1.5 \mathrm{~min}$. Vicat apparatus (Solotest, 1.111.001) was used to determine the false setting. The paste had no false setting when the Tetmajer probe of the Vicat equipment reached a value $\geq 33$ $\mathrm{mm}$ of the base plate after $30 \mathrm{~s}$, starting from the instant it was released.

Characterization of materials: the raw materials and CPI-S-32 were characterized according to NBR
14656 standard [15]. X-ray fluorescence spectroscopy (XRF) was performed with a spectrometer (Oxford Instr., $\mathrm{X}$-Supreme8000) with incident radiation energy of $10 \mathrm{keV}$. Cast pellets were produced in a Vulcan Fusion machine (FluXana, 2M). Pressed pellets for the gypsum and CPI-S-32 samples were made in a hydraulic press (Carver, 3853-0), at a pressure of $15.0 \mathrm{kgf} / \mathrm{cm}^{2}$. The analyzes performed in the physicochemical characterization of CPI-S-32 were loss on ignition (LOI) [16-19], insoluble residue [20], magnesium oxide and sulfur trioxide contents, specific mass [21], retention index with a $75 \mu \mathrm{m}$ sieve [22], normal paste consistency [23], initial and final setting time [24], LeChatelier's heat expansion [25], and specific area [26] after different cement storage temperatures and times in a silo. By the X-ray diffraction (XRD) analysis, the crystalline phases of the CPI-S-32 cement samples were identified employing a diffractometer (Bruker, D8 Advance) with $\mathrm{CuK} \alpha$ radiation, $40 \mathrm{kV}$ voltage, $40 \mathrm{~mA}$ current, $2 \theta$ range from $2^{\circ}$ to $65^{\circ}$, a scan speed of $1^{\circ} \cdot \mathrm{min}^{-1}$, step width of $0.02^{\circ}$, and time step of $0.2 \mathrm{~s}$. The mineral crystalline phases were identified using the MATCH! analysis program, in which the ICSD (Inorganic Crystal Structure Database) crystallographic files were inserted $[27,28]$. The thermogravimetry/derivative thermogravimetry (TG/DTG) of CPI-S-32 was performed in a thermal analyzer (Netzsch, STA 449 F1 Jupiter) using an aluminum crucible and a flow rate of $100 \mathrm{~mL} \cdot \mathrm{min}^{-1}$ of $\mathrm{N}_{2}$ from 25 to $1200{ }^{\circ} \mathrm{C}$ using a heating rate of $10{ }^{\circ} \mathrm{C} \cdot \mathrm{min}^{-1}$. The CPI-S-32 samples in powder form were dispersed on a carbon tape and coated with a thin layer of gold in a metallizer (Kurt J Lesker, 108) and then analyzed using a scanning electron microscope (SEM, Jeol, JJSM-6510LV).

\section{RESULTS AND DISCUSSION}

The loss on ignition and compositions of raw materials in terms of oxides used in the preparation of CPI-S-32 samples are shown in Table II. The low loss on ignition value of clinker was due to the decomposition of all organic material and volatiles of the mixture of limestone, clay, and correctives during the clinkerization process. In contrast to the clinker, the limestone showed a higher loss on ignition value combined with the presence of a significant quantity of $\mathrm{CO}_{2}$ in its composition. As loss on ignition is a chemical requisite established by NBR 16697 standard for CPI-S-32, the added quantity of limestone is limited due to its high values of loss on ignition. As observed in the clinker, the calcium and silicon oxides were the main constituents, corresponding to an amount higher than $80.0 \%$ of the chemical composition, proving that clinker is a product that is mostly composed of calcium silicates [3]. For gypsum, the presence of the main components calcium oxide and sulfur trioxide was observed (Table II) with percentages of 32.90\% and $40.29 \%$, respectively. The presence of these compounds related to the chemical composition of calcium sulfate was much higher than the other oxides present in the gypsum composition. According to the literature [29], the mean stoichiometric composition of gypsum is around $32.0 \%$ 
Table II - Loss on ignition (LOI) and chemical composition of raw materials by XRF (wt\%).

[Tabela II - Perda ao fogo (LOI) e composição química das matérias-primas por FRX (\% em massa).]

\begin{tabular}{ccccccccc}
\hline Raw material & LOI & $\mathrm{SiO}_{2}$ & $\mathrm{Al}_{2} \mathrm{O}_{3}$ & $\mathrm{Fe}_{2} \mathrm{O}_{3}$ & $\mathrm{CaO}$ & $\mathrm{MgO}$ & $\mathrm{SO}_{3}$ & Other oxides $^{1}$ \\
\hline Clinker & 0.41 & 19.84 & 4.95 & 3.89 & 65.06 & 4.31 & 0.44 & $<0.50$ \\
Gypsum & 19.10 & 4.91 & 0.89 & 0.52 & 32.90 & 0.52 & 40.29 & $<1.00$ \\
Limestone & 38.59 & 7.95 & 1.44 & 0.85 & 45.22 & 4.63 & - & $<1.50$ \\
\hline
\end{tabular}

${ }_{-}-\mathrm{K}_{2} \mathrm{O}+\mathrm{Na}_{2} \mathrm{O}+\mathrm{TiO}_{2}+\mathrm{P}_{2} \mathrm{O}_{5}+\mathrm{SrO}$.

$\mathrm{CaO}$ and $45.0 \% \mathrm{SO}_{3}$. A predominance of calcium oxide is observed in the limestone composition with a content higher than $45.0 \%$. The limestone added to the mixture of clinker and gypsum for the production of CPI-S-32 contained $85.7 \% \mathrm{CaCO}_{3}$, which constituted a value higher than $75 \%$ established by NBR 16697 as a condition to add carbonate materials.

Table III shows the result of the percentage of CPI-S-32 retained in the $75 \mu \mathrm{m}$ sieve, a procedure performed before determining the CPI-S false setting. It was noted that the evaluated granulometry was below the limit established by NBR 16697 and equal to $0.50 \%$ retained in the $75 \mu \mathrm{m}$ sieve. Table IV presents the false setting values for the CPI-S-32 cement samples. It was verified that the storage temperature and time of the cement in the silo influenced the false setting behavior of the cement. It was verified that CPI-S-32 samples were falsely adjusted for cement storage temperatures above $110{ }^{\circ} \mathrm{C}$ and silo storage time over $60 \mathrm{~min}$ due to gypsum dehydration reactions and hemihydrate formation above 106 ${ }^{\circ} \mathrm{C}$ [12]. It was also observed that the CPI-S-32 presented a false setting of $29 \mathrm{~mm}$ when the storage temperature was $110{ }^{\circ} \mathrm{C}$ and the cement storage time was $60 \mathrm{~min}$, which represented a much higher value when compared to the CPI-S-32 samples that presented no false setting. There was a transition stage in these specific experimental conditions where there was a need for a deeper investigation in terms of dehydration kinetics to more accurately verify the onset on the loss of plasticity in the CPI-S until its premature stiffness.

After suffering a dehydration process, the gypsum (calcium sulfate dihydrate) contained in the clinker mixture forms calcium sulfate hemihydrate between its products, which deposits dihydrate crystals due to having a higher solubility than gypsum, thereby causing the paste to stiffen $[7,8,11]$. This result was confirmed by the XRD analyses, which showed that the cement with false setting behavior lost the characteristic gypsum peak when compared to the cement that did not show a false setting. The CPI-S-32 storage time in the silo only influences the false setting of the CPI-S-32 if combined with any factor that may cause an anomaly in the cement. Table IV shows that the false adjustment occurred in all CPI-S-32 samples for storage time above $60 \mathrm{~min}$ and temperatures above $110{ }^{\circ} \mathrm{C}$. This occurred due to the compaction effect of the cement inside the silo since the temperature of cement grains rises, causing advanced stiffening of the cement paste. However, it was also observed that the cement samples in the studied
Table III - Fineness of CPI-S-32 retained in the $75 \mu \mathrm{m}$ sieve. [Tabela III - Finura do CPI-S-32 retido na peneira de $75 \mu \mathrm{m}$.]

\begin{tabular}{ccc}
\hline Sample & $\begin{array}{c}75 \mu \mathrm{m} \text { sieve } \\
(\%)\end{array}$ & $\begin{array}{c}\text { NBR 16697 limit } \\
(\%)\end{array}$ \\
\hline CPI-S-32 & 0.50 & $\leq 12.0$ \\
\hline
\end{tabular}

Table IV - False setting values obtained for CPI-S-32 at different experimental conditions.

[Tabela IV - Valores obtidos de falsa pega do CPI-S-32 para diferentes condições experimentais.]

\begin{tabular}{cc}
\hline CPI-S-32 sample & False setting* $(\mathrm{mm})$ \\
\hline CPI-S 100.30 & 40 \\
CPI-S 100.60 & 40 \\
CPI-S 100.120 & 40 \\
CPI-S 105.30 & 40 \\
CPI-S 105.60 & 40 \\
CPI-S 105.120 & 40 \\
CPI-S 110.30 & 40 \\
CPI-S 110.60 & 29 \\
CPI-S 110.120 & 3 \\
CPI-S 120.30 & 40 \\
CPI-S 120.60 & 3 \\
CPI-S 120.120 & 0 \\
CPI-S 130.30 & 40 \\
CPI-S 130.60 & 0 \\
CPI-S 130.120 & 0 \\
\hline
\end{tabular}

* - no false setting for values $\geq 33 \mathrm{~mm}$.

temperatures did not show false setting behavior for storage periods close to $30 \mathrm{~min}$, from which it was inferred that there was not enough time for the stored cement to suffer a compaction process and consequently an increase in the grain temperature, and thus the false setting was not possible.

The results obtained for the chemical requirements of loss on ignition and insoluble residue of the CPI-S-32 samples for all storage temperature range and storage time in a silo are shown in Table V. All the produced CPI-S-32 samples presented loss on ignition values below $6.5 \%$, which is the limit established by NBR 16697. It was also noticed that the loss on ignition values did not have a major change when comparing the six samples presenting a false 
setting to those which did not. Thus, the mass loss of the cement after heating in a furnace around $1000{ }^{\circ} \mathrm{C}$ was maintained stable for all the storage temperature and time

Table V - Loss on ignition and insoluble residue values of CPI-S.

[Tabela $V$ - Valores de perda ao fogo e resíduo insolúvel do CPI-S-32.]

\begin{tabular}{ccc}
\hline CPI-S-32 sample & $\begin{array}{c}\text { Loss on } \\
\text { ignition (\%) }\end{array}$ & $\begin{array}{c}\text { Insoluble } \\
\text { residue (\%) }\end{array}$ \\
\hline CPI-S 100.30 & 4.03 & 0.76 \\
CPI-S 100.60 & 4.06 & 0.62 \\
CPI-S 100.120 & 3.84 & 0.80 \\
CPI-S 105.30 & 4.03 & 0.95 \\
CPI-S 105.60 & 3.64 & 0.77 \\
CPI-S 105.120 & 3.45 & 0.97 \\
CPI-S 110.30 & 4.44 & 1.07 \\
CPI-S 110.60 & 4.23 & 0.75 \\
CPI-S 110.120 & 4.01 & 0.92 \\
CPI-S 120.30 & 3.99 & 0.94 \\
CPI-S 120.60 & 3.81 & 1.01 \\
CPI-S 120.120 & 3.83 & 0.76 \\
CPI-S 130.30 & 3.77 & 0.86 \\
CPI-S 130.60 & 3.53 & 0.91 \\
CPI-S 130.120 & 3.64 & 0.82 \\
\hline
\end{tabular}

ranges in a silo. Also, the insoluble residue calculated for all conditions showed values less than $3.5 \%$, which is the limit established by NBR 16697. This showed that the false setting phenomena of the studied CPI-S-32 samples did not influence the chemical properties of the insoluble residue.

Table VI shows the obtained results for the physical requisites of the specific mass, normal paste consistency, initial and final setting time, heat expansion, and specific area for both the CPI-S-32 samples, which presented false setting behavior as compared to the ones which did not. It was possible to verify that the specific mass of the cement samples which presented false setting behavior was similar to the samples which did not show alteration. Although it is an optional requisite, its determination is fundamental to calculate the specific area of CPI-S samples. A normal paste consistency was obtained with enough water to provide a standardized pattern. The test value is presented in terms of water/cement mass ratio, which indicated how much water the CPI-S demanded to produce a workable concrete. According to the results, a slight percentage increase of water was needed to produce a workable paste with the increase in both the CPI-S-32 storage temperature and time in the silo. This is probably justified on the dehydration process suffered by the calcium sulfate dehydrated $[8,10]$, as proven by the XRD analyses of the CPI-S cement 130.120 when compared to CPI-S 100.30. The determination of normal paste consistency identified the necessary quantity of water to be added to the cement for the determination tests of initial and final setting time, constituting a normative physical requisite for CPI-S production.

Table VI - Physical requirements of specific mass, normal consistency, initial and final setting times, heat expansion, and specific area of CPI-S-32.

[Tabela VI - Requisitos físicos de massa específica, consistência normal, tempo de início e fim de pega, expansibilidade a quente e área específica das amostras de CPI-S-32.]

\begin{tabular}{ccccccc}
\hline $\begin{array}{c}\text { CPI-S-32 } \\
\text { sample }\end{array}$ & $\begin{array}{c}\text { Specific mass } \\
\left(\mathrm{g} / \mathrm{cm}^{3}\right)\end{array}$ & $\begin{array}{c}\text { Normal } \\
\text { consistency }(\%)\end{array}$ & $\begin{array}{c}\text { Initial setting } \\
(\mathrm{h}: \mathrm{min})\end{array}$ & $\begin{array}{c}\text { Final setting } \\
(\mathrm{h}: \mathrm{min})\end{array}$ & $\begin{array}{c}\text { Heat expansion } \\
(\mathrm{mm})\end{array}$ & $\begin{array}{c}\text { Specific area } \\
\left(\mathrm{m}^{2} / \mathrm{kg}\right)\end{array}$ \\
\hline CPI-S 100.30 & 3.09 & 25.0 & $3: 10$ & $4: 05$ & 0.5 & 386 \\
CPI-S 100.60 & 3.10 & 25.0 & $3: 05$ & $4: 00$ & 0.5 & 385 \\
CPI-S 100.120 & 3.11 & 25.2 & $3: 20$ & $4: 10$ & 0.5 & 385 \\
CPI-S 105.30 & 3.09 & 25.6 & $3: 05$ & $4: 15$ & 0.8 & 386 \\
CPI-S 105.60 & 3.12 & 25.0 & $2: 50$ & $4: 15$ & 0.5 & 384 \\
CPI-S 105.120 & 3.11 & 26.4 & $3: 15$ & $4: 40$ & 0.0 & 385 \\
CPI-S 110.30 & 3.11 & 25.0 & $3: 00$ & $4: 05$ & 0.5 & 385 \\
CPI-S 110.60 & 3.11 & 25.6 & $3: 35$ & $4: 25$ & 1.0 & 384 \\
CPI-S 110.120 & 3.10 & 26.6 & $3: 50$ & $5: 00$ & 0.0 & 385 \\
CPI-S 120.30 & 3.11 & 25.4 & $3: 05$ & $4: 10$ & 0.0 & 385 \\
CPI-S 120.60 & 3.12 & 26.6 & $3: 35$ & $4: 45$ & 0.0 & 385 \\
CPI-S 120.120 & 3.11 & 28.0 & $3: 55$ & $5: 00$ & 0.0 & 385 \\
CPI-S 130.30 & 3.12 & 26.0 & $3: 55$ & $4: 30$ & 0.5 & 386 \\
CPI-S 130.60 & 3.12 & 28.0 & $3: 50$ & $4: 55$ & 0.0 & 386 \\
CPI-S 130.120 & 3.13 & 30.4 & $4: 00$ & $5: 05$ & 0.0 & 385 \\
\hline
\end{tabular}


Table VII - Chemical composition of CPI-S-32 samples by XRF (wt $\%$ ).

[Tabela VII - Composição química das amostras de CPI-S-32 por FRX (\% em massa).]

\begin{tabular}{cccccccccccc}
\hline CPI-S-32 sample & $\mathrm{SiO}_{2}$ & $\mathrm{Al}_{2} \mathrm{O}_{3}$ & $\mathrm{Fe}_{2} \mathrm{O}_{3}$ & $\mathrm{CaO}$ & $\mathrm{MgO}$ & $\mathrm{SO}_{3}$ & $\mathrm{P}_{2} \mathrm{O}_{5}$ & $\mathrm{TiO}_{2}$ & $\mathrm{Na}_{2} \mathrm{O}$ & $\mathrm{K}_{2} \mathrm{O}$ & $\mathrm{SrO}$ \\
\hline CPI-S 100.30 & 18.65 & 4.56 & 3.96 & 65.12 & 3.79 & 2.98 & 0.33 & 0.24 & 0.05 & 0.20 & 0.08 \\
$\mathrm{CPI}-\mathrm{S} \mathrm{100.60}$ & 18.55 & 4.62 & 3.93 & 65.32 & 3.71 & 2.99 & 0.33 & 0.24 & 0.05 & 0.19 & 0.08 \\
$\mathrm{CPI}-\mathrm{S} \mathrm{100.120}$ & 18.64 & 4.50 & 3.95 & 65.37 & 3.72 & 2.98 & 0.33 & 0.23 & 0.04 & 0.18 & 0.08 \\
$\mathrm{CPI}-\mathrm{S} \mathrm{105.30}$ & 18.61 & 4.62 & 3.96 & 65.29 & 3.76 & 2.88 & 0.32 & 0.24 & 0.05 & 0.18 & 0.07 \\
$\mathrm{CPI}-\mathrm{S} \mathrm{105.60}$ & 18.47 & 4.51 & 3.98 & 65.62 & 3.70 & 2.87 & 0.33 & 0.24 & 0.03 & 0.19 & 0.07 \\
$\mathrm{CPI}-\mathrm{S} \mathrm{105.120}$ & 18.56 & 4.57 & 3.97 & 65.23 & 3.84 & 2.94 & 0.34 & 0.24 & 0.04 & 0.19 & 0.08 \\
CPI-S 110.30 & 18.46 & 4.57 & 3.97 & 65.33 & 3.72 & 2.99 & 0.34 & 0.25 & 0.05 & 0.19 & 0.10 \\
CPI-S 110.60 & 18.52 & 4.58 & 3.95 & 65.19 & 3.83 & 3.03 & 0.33 & 0.25 & 0.04 & 0.20 & 0.08 \\
CPI-S 110.120 & 18.68 & 4.56 & 3.94 & 65.03 & 3.87 & 3.02 & 0.33 & 0.24 & 0.04 & 0.20 & 0.08 \\
CPI-S 120.30 & 18.72 & 4.63 & 3.94 & 65.04 & 3.79 & 2.98 & 0.34 & 0.24 & 0.06 & 0.20 & 0.07 \\
CPI-S 120.60 & 18.50 & 4.53 & 3.96 & 65.32 & 3.75 & 3.03 & 0.35 & 0.23 & 0.05 & 0.18 & 0.07 \\
CPI-S 120.120 & 18.54 & 4.52 & 3.95 & 65.30 & 3.80 & 3.01 & 0.33 & 0.23 & 0.04 & 0.18 & 0.08 \\
CPI-S 130.30 & 18.56 & 4.56 & 3.96 & 65.35 & 3.76 & 2.91 & 0.33 & 0.24 & 0.04 & 0.19 & 0.10 \\
CPI-S 130.60 & 18.46 & 4.53 & 3.98 & 65.43 & 3.79 & 2.91 & 0.34 & 0.24 & 0.04 & 0.20 & 0.08 \\
CPI-S 130.120 & 18.44 & 4.52 & 3.97 & 65.46 & 3.78 & 2.92 & 0.34 & 0.25 & 0.05 & 0.20 & 0.08 \\
\hline
\end{tabular}

In evaluating the setting times, all the CPI-S-32 samples presented an initial setting time longer than $1 \mathrm{~h}$, which is the limit established by NBR 16697 as the physical demand in CPI-S-32 production and a final setting time less than $10 \mathrm{~h}$. The results showed that all samples which presented false setting behavior had more difficulties for plasticity loss of the water and cement mixture, which meant longer times of setting, showing that the increase in temperature caused an increase in the initial and final setting time of this cement $[7,10]$. All CPI-S-32 samples exhibited LeChatelier heat expansion values less than $5.0 \mathrm{~mm}$, which is the limit imposed by NBR 16697. This meant that all CPI-S-32 samples did not present volumetric variation due to the hydration process of cement $[3,7]$. It was noted that the specific area of the samples of CPI-S cement presented values with low variation, both for samples that presented false setting and those that not. The specific area had a direct relationship with the cement granulometry due to the grains presenting in its composition; moreover, the CPI-S samples were prepared with the same granulometry (retained material in $75 \mu \mathrm{m}$ sieve), justifying the obtained results.

Table VII presents the chemical constituents of the CPI-S-32 samples. The calcium and silicon oxides were the major constituents in the studied samples and together were responsible for the hydration reactions of silicates, corresponding to more than $60 \%$ of volume in the cement reactions [6]. The variation of the calcium and silicon elements in the cement directly interferes in the $\mathrm{C}_{3} \mathrm{~S}$ and $\mathrm{C}_{2} \mathrm{~S}$ anhydrous phases, in which a higher concentration of calcium leads to a preponderant production of alite, and is the main element responsible for the hydrated C-S-H and $\mathrm{Ca}(\mathrm{OH})_{2}$ phases $[30,31]$. The aluminum and iron oxides are no less important, being responsible for aluminate reactions and corresponding to $20 \%$ of the volume of the reactions which occur in the cement. The oxide percentages were not influenced by the false setting phenomena of the CPI-S-32 samples. The magnesium oxide and sulfur trioxide were below the values required by NBR 16697, being lower than $6.5 \%$ and $4.5 \%$, respectively. The low $\mathrm{MgO}$ content makes the CPI-S-32 normally self-hydratable and loses the capacity to cause cracks by expanding inside the already hardened concrete. Likewise, low values of $\mathrm{SO}_{3}$ originated from the gypsum decreases the possibility of interference in the initial strength of the cement, as shown by theoretical studies [10].

X-ray diffraction (Fig. 1) and TG/DTG analyses (Fig. 2) were performed on two CPI-S-32 samples, sample CPI-S-32 130.120, which presented false setting, and CPI-S-32 100.30 sample, which did not show false setting. It was possible to note the presence of the main crystalline compounds in both samples as alite $\left(\mathrm{C}_{3} \mathrm{~S}\right)$, belite $\left(\mathrm{C}_{2} \mathrm{~S}\right)$, tricalcium aluminate $\left(\mathrm{C}_{3} \mathrm{~A}\right)$, tetracalcium ferroaluminate (C4AF), and calcite $\left(\mathrm{CaCO}_{3}\right)$ [32-39]. In addition to these compounds, the presence of gypsum $\left(\mathrm{CaSO}_{4} .2 \mathrm{H}_{2} \mathrm{O}\right)$ was observed in the CPI-S-32 100.30 sample at $11.6^{\circ}$ and $20.8^{\circ}$ (20). Also, the disappearance of dihydrated calcium sulfate peaks was observed in the CPI-S-32 130.120 sample, since the gypsum was consumed by dehydration process forming basanite $\left(\mathrm{CaSO}_{4} \cdot 0.5 \mathrm{H}_{2} \mathrm{O}\right)$. As this compound is about 5 times more soluble than gypsum, it allowed the formation of a supersaturated solution that tended to deposit dihydrate crystals, which caused early stiffness in the mass of CPI-S-32 130.120, characterizing the false setting in this studied sample [7, 8, 10-12].

The results of thermogravimetric analysis (TG/DTG) for the CPI-S-32 100.30 and CPI-S-32 130.120 samples are presented in Fig. 2. The CPI-S-32 samples presented 


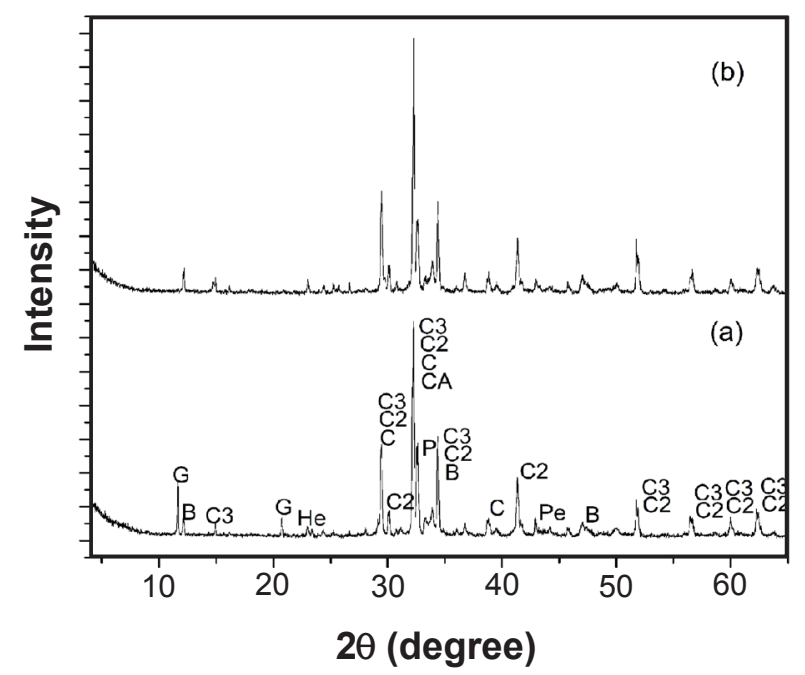

Figure 1: X-ray diffraction patterns of CPI-S-32 100.30 (a) and CPI-S-32 130.120 (b) samples. C3: alite; C2: belite; CA: tricalcium aluminate; C: calcite; B: brownmilerite; G: gypsum; Pe: periclase; He: hematite.

[Figura 1: Difratogramas de raios $X$ das amostras CPI-S-32 100.30 (a) e CPI-S-32 130.120 (b). C3: alita; C2: belita; CA: aluminato tricálcico; $C$ : calcita; B: brownmilerita; G: gipsita; Pe: periclásio; He: hematite.] continuous mass loss with lower or larger loss rates in the analyzed temperature range. The thermograms of the CPI-S-32 100.30 and CPI-S-32 130.120 samples showed the decomposition in three stages. The first occurred between 30 and $180{ }^{\circ} \mathrm{C}$, with the highest band maximum identified by the DTG at $130{ }^{\circ} \mathrm{C}$ being attributed to water loss from the dehydration of calcium sulfate dihydrate, equivalent to $1.3 \%$ for CPI-S-32 100.30 and $0.2 \%$ for CPI-S-32 130.120. Between 180 and $500{ }^{\circ} \mathrm{C}$, the highest band value at 440 ${ }^{\circ} \mathrm{C}$ was observed with a mass loss of $0.7 \%$ for CPI-S-32 100.30 and $0.6 \%$ for CPI-S-32 130.120 , corresponding to dehydration of calcium hydroxide [40]. Then between 500 and $800{ }^{\circ} \mathrm{C}$, at the highest band maximum at $730{ }^{\circ} \mathrm{C}$, mass losses of $3.2 \%$ for CPI-S-32 100.30 and $3.4 \%$ for CPI-S-32 130.120 were observed due to the loss of $\mathrm{CO}_{2}$ by decomposition of calcium carbonate. Thus, the total mass loss was $5.2 \%$ for CPI-S-32 100.30 and $4.2 \%$ for CPI-S-32 130.120. Accordingly, it was verified that the mass loss of the CPI-S 100.30 sample was higher than CPI-S 130.120 because of the higher dehydration mass loss of calcium sulfate dehydrate. It was observed that the decomposition band of dehydrated calcium sulfate of the CPI-S 130.120 cement was smaller than that of the CPI-S 100.30 cement,
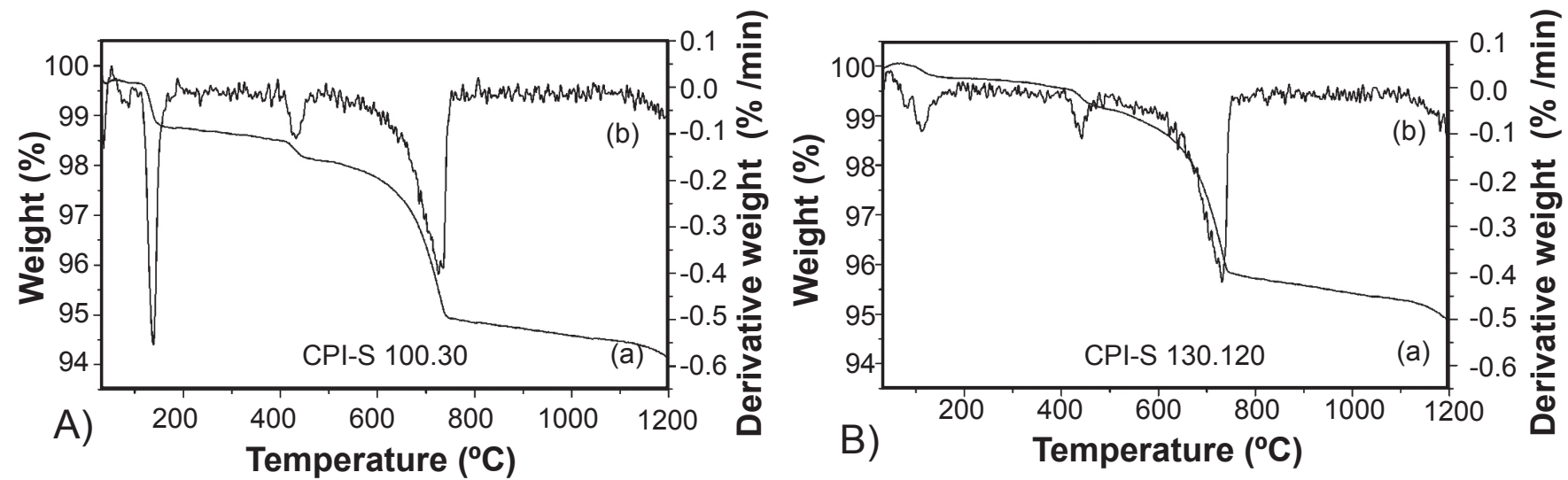

Figure 2: TG (a) and DTG (b) curves of the CPI-S-32 100.30 (A) and CPI-S-32 130.120 (B) cement samples.

[Figura 2: Curvas de TG (a) e DTG (b) das amostras CPI-S-32 100.30 (A) e CPI-S-32 130.120 (B).]
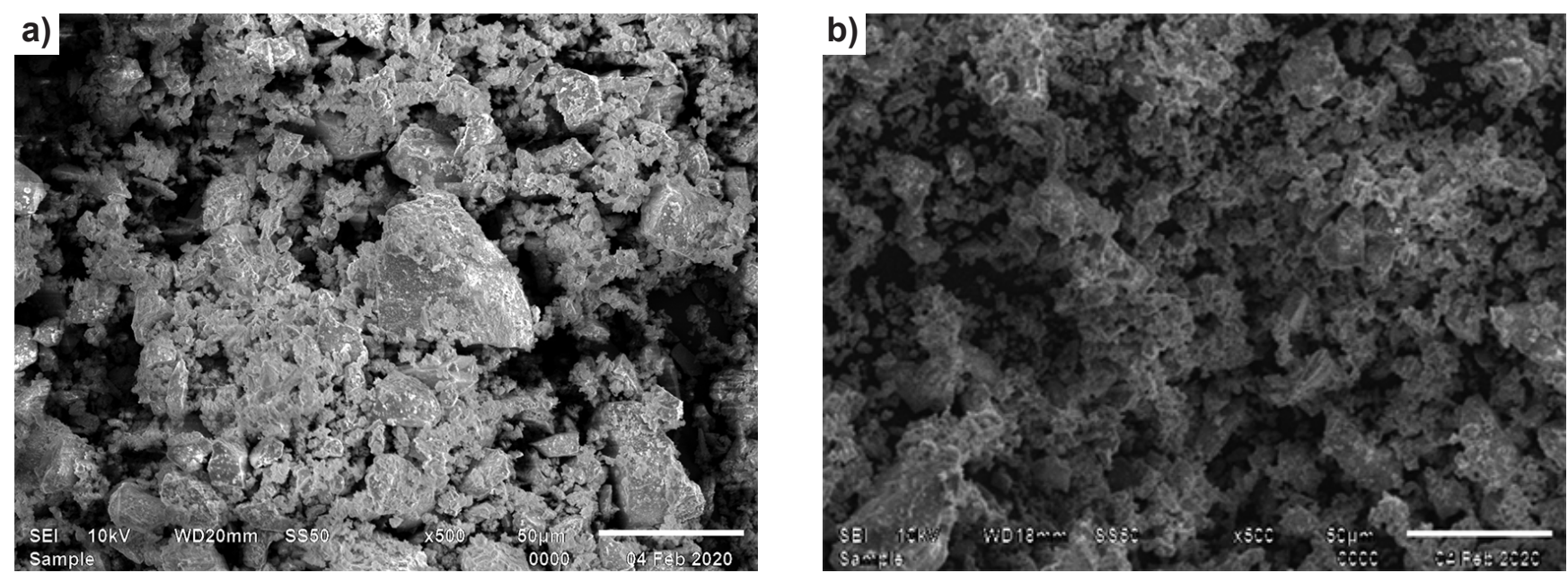

Figure 3: SEM micrographs of the samples CPI-S-32 100.30 (a) and CPI-S-32 130.120 (b).

[Figura 3: Micrografias de MEV das amostras CPI-S-32 100.30 (a) e CPI-S-32 130.120 (b).] 
probably due to the partial or total decomposition of dehydrated calcium sulfate added during the storage, which can transform into hemihydrate calcium sulfate.

Analyzing Fig. 3, it was noted that the sample CPI-S-32 130.120 had a uniform morphology and little porosity, compared to the sample CPI-S-32 100.30, which can be attributed to the interaction temperature and time used. Probably this little porosity made it difficult to hydrate the constituents of the cement, which may have led to a false setting.

\section{CONCLUSIONS}

Based on the performed tests and analyses, it was concluded that the storage temperature above $110^{\circ} \mathrm{C}$ and the storage time of CPI-S-32 above $60 \mathrm{~min}$ influenced the false setting behavior of cement. Six of 15 samples of analyzed cement showed this anomaly, with the cement paste stiffening instantaneously without the release of characteristic heat. The false setting did not influence the parameters of loss on ignition, insoluble residue, fineness retained in the $75 \mu \mathrm{m}$ sieve, $\mathrm{MgO}$ and $\mathrm{SO}_{3}$ content, initial and final setting time, heat expansion, specific mass, specific area, and normal paste consistency as established by NBR 16697 standard. $\mathrm{X}$-ray diffraction analysis showed in a cement sample with false setting behavior (CPI-S-32 130.120 - stored at $130{ }^{\circ} \mathrm{C}$ and $120 \mathrm{~min}$ ) the absence of $\mathrm{CaSO}_{4} \cdot 2 \mathrm{H}_{2} \mathrm{O}$ phase, since the gypsum was consumed by the dehydration process during the storage stage and transformed into $\mathrm{CaSO}_{4} \cdot 0.5 \mathrm{H}_{2} \mathrm{O}$, differently from that observed in a sample that did not show false setting (CPI-S-32 100.30 - stored at $100{ }^{\circ} \mathrm{C}$ and 30 $\mathrm{min}$ ) in which the gypsum was present. This was confirmed by thermogravimetric analysis that showed a higher mass loss of the CPI-S-32 100.30 cement sample (5.2\%) than the CPI-S-32 130.120 cement (4.2\%), which the difference mainly occurred between 30 and $180{ }^{\circ} \mathrm{C}$ when water loss from the dehydration of the calcium sulfate dihydrate occurred. In the other temperature ranges, the mass losses by calcium hydroxide dehydration and due to the loss of $\mathrm{CO}_{2}$ by decomposition of calcium carbonate were similar. The results showed the optimal operating conditions of the storage temperature and time of the cement in order to avoid false setting and a loss in the CPI-S-32 product quality. It was identified that the CPI-S-32 could present a false setting in the storage temperature range of 110 to $130{ }^{\circ} \mathrm{C}$ combined with storage time from 60 to $120 \mathrm{~min}$, which causes financial loss to the industry. As a false setting is a specific quality parameter, mainly for CPI-S-32 cement, its control is necessary to attend the consumers. Higher consumption of energy and raw materials can be avoided by knowing that the temperature and the storage time of the cement in silos are variables that need to be controlled by the cement industry.

\section{ACKNOWLEDGMENTS}

The authors are grateful to CAPES, FAPITEC-SE, the
Federal University of Sergipe, the Laboratory of Industrial Chemistry, and LMDCEM/UFS for their support in the accomplishment and participation of the obtained results. To the cement industry located in Capanema-PA, for the supply of clinker, gypsum, and limestone and support in carrying out the experimental activities.

\section{REFERENCES}

[1] E.I. El-Shafey, S.N.F. Ali, S. Al-Busai, H.A.J. Al-Lawati, J. Environ. Chem. Eng. 4 (2016) 2713.

[2] J.P. Lopes, T. Rudnick, C.H. Martins, Rev. Eletr. Eng. Civil 14 (2018) 216.

[3] ABNT NBR 16697, "Cimento Portland: requisitos", Ass. Bras. Norm. Técn., Rio Janeiro (2018).

[4] R. Pilar, R.A. Schankoski, A.J. Dal Moro, W.L. Repette, Matéria 21 (2016) 92.

[5] S. Demirhan, K. Turk, K. Ulugerger, Constr. Build. Mater. 196 (2019) 115.

[6] W.P. Gonçalves, V.J. Silva, J. Gomes, R.R. Menezes, G.A. Neves, H.C. Ferreira, L.N.L. Santana, Cerâmica 60, 355 (2014) 316.

[7] A.M. Neville, J.J. Brooks, Tecnologia do concreto, 2 ed., Bookman. Porto Alegre (2013) 448.

[8] P.K. Mehta, P.J.M. Monteiro, Concreto: microestrutura, propriedades e materiais, 2 ed., IBRACON, S. Paulo (2014) 782.

[9] E. Gartner, I. Maruyama, J. Chen, Cem. Concr. Res. 97 (2017) 95.

[10] A.M. Neville, Propriedades do concreto, 5 ed., Bookman, Porto Alegre (2016) 912.

[11] F.L.A Bauer, Materiais de construção, 5 ed., LTC (2000) 471.

[12] S.M. Pinheiro, "Gesso reciclado: avaliação das propriedades para uso em componentes", Tese Dout., Unicamp, Campinas (2011) 304.

[13] V.M. John, M.A. Cincotto, in "Materiais de construção civil”, G.C. Isaia (Ed.), Ibracon, S. Paulo (2007) 727.

[14] ASTM C451-13, "Standard test method for early stiffening of hydraulic cement (paste method)", Am. Soc. Test. Mater. (2013).

[15] ABNT NBR 14656, "Cimento Portland e matériasprimas: análise química por espectrometria de raios $\mathrm{X}$, método de ensaio", Ass. Bras. Norm. Técn., Rio Janeiro (2001).

[16] ABNT NBR NM 18, "Cimento Portland: análise química, determinação de perda ao fogo", Ass. Bras. Norm. Técn., Rio Janeiro (2012).

[17] R.R. Menezes, M.M. Ávila Júnior, L.N.L. Santana, G.A. Neves, H.C. Ferreira, Cerâmica 54, 330 (2008) 152.

[18] M.G. Silva-Valenzuela, M.M. Chambi-Peralta, I.J. Sayeg, F.M. de Souza Carvalho, S.H. Wang, F.R. ValenzuelaDíaz, Appl. Clay Sci. 155 (2018) 111.

[19] S.H. Ngo, T.P. Huynh, T.T.T. Le, N.H.T. Mai, IOP Conf. Ser. Mater. Sci. Eng. 371 (2018) 12007.

[20] ABNT NBR NM 15, "Cimento Portland: análise química, determinação de resíduo insolúvel”, Ass. Bras. 
Norm. Técn., Rio Janeiro (2012).

[21] ABNT NBR 16605, "Cimento Portland e outros materiais em pó: determinação da massa específica", Ass. Bras. Norm. Técn., Rio Janeiro (2017).

[22] ABNT NBR 12826, "Cimento Portland e outros materiais em pó: determinação do índice de finura por meio de peneirador aerodinâmico", Ass. Bras. Norm. Técn., Rio Janeiro (2014).

[23] ABNT NBR 16606, "Cimento Portland: determinação da pasta de consistência normal", Ass. Bras. Norm. Técn., Rio Janeiro (2017).

[24] ABNT NBR 16607, "Cimento Portland: determinação dos tempos de pega", Ass. Bras. Norm. Técn., Rio Janeiro (2017).

[25] ABNT NBR 11582, "Cimento Portland: determinação da expansibilidade de Le Chatelier", Ass. Bras. Norm. Técn., Rio Janeiro (2016).

[26] ABNT NBR 16372, "Cimento Portland e outros materiais em pó: determinação da finura pelo método de permeabilidade ao ar (método de Blaine)", Ass. Bras. Norm. Técn., Rio Janeiro (2015).

[27] A.C.S. Alcântara, M.S.S. Beltrão, H.A. Oliveira, I.F. Gimenez, L.S. Barreto, Appl. Clay Sci. 39 (2008) 160.

[28] C.P. Santos, H.A. Oliveira, R.M.P.B. Oliveira, Z.S. Macedo, Cerâmica 62, 362 (2016) 147.

[29] K.K.S. Melo, A.P.C. Lima, M.C. Santana, V.C.P. Andrade, A.L.C. Braga, K.V. Correia, Holos 6 (2017) 194.
[30] L. Simão, N.J. Lóh, D. Hotza, F. Raupp-Pereira, J.A. Labrincha, O.R.K. Montedo, Cerâmica 64, 371 (2018) 311. [31] J.E.F. Nascimento, A.C.V. Nóbrega, H.C. Ferreira, G.A. Neves, L.N.L. Santana, Cerâmica 65, 373 (2019) 85.

[32] R.C.O. Romano, A.L. Fujii, R.B. Souza, M.S. Takeashi, R.G. Pileggi, M.A. Cincotto, Cerâmica 62, 363 (2016) 215. [33] P.C. Aïtcin, R.J. Flatt, Science and technology of concrete admixtures, Woodhead Publ. (2016) 666.

[34] T.R.S. Nobre, T.A. Santos, R.A. Argolo, Ribeiro, D.V. Ribeiro, in VIII Enc. Cient. Fís. Apl., Blucher Proc. (2017) 49.

[35] E.G.A. Ferreira, F. Yokaichiya, J.T. Marumo, R. Vicente, F. Garcia-Moreno, P.H. Kammc, M. Klaus, M. Russina, G. Gunther, C.E. Jimenez, M.K.K.D. Franco, Physica B Condens. Matter 551 (2018) 256.

[36] W.H. Duda, Manual tecnológico del cemento, Edit. Técn. Asoc., Barcelona (1977) 332.

[37] M.C.G. Juenger, F. Winnefeld, J.L. Provis, J.H. Ideker, Cem. Concr. Res. 41 (2011) 1232.

[38] O. Labahn, Prontuario del cemento, 5 ed., Edit. Técn. Asoc., Barcelona (1985) 1016.

[39] H.F.W. Taylor, Cement chemistry, 2 ed., Thomas Telford, London (1997) 102.

[40] J. Hoppe Filho, A. Gobbi, E. Pereira, R.S. Tanaka, M.H.F. Medeiros, Matéria 22 (2017) 18.

(Rec. 13/12/2019, Rev. 08/02/2020, 06/04/2020, Ac. 09/04/2020) 